\title{
CORAK PESANTREN AL AZIZIYAH DESA GUNUNGSARI KABUPATEN LOMBOK BARAT PROPINSI NUSA TENGGARA BARAT
}

\author{
Oleh : Abd. Azis Al Bone
}

\section{PENDAHULUAN}

Pesantren merupakan lembaga pendidikan Islam tertua di Indonesia. Lembaga ini tumbuh dan berkembang bersama irama perkembangan Islam itu sendiri, terutama pada daerah-daerah dan pusat-pusat perkembangan Islam. Semula pesantren lebih merupakan lembaga pendidikan Islam yang dijadikan wadah untuk mempelajari agama dan kepentingan penyebaran Islam. Akan tetapi dalam perjalanan selanjutnya pesantren semakin mengalami ekspansi sosial dan ekonomi umat, bahkan merupakan unsur dinamis bagi suatu komunitas, unsur elit dan pelopor pengembangan masyarakat.

Meski dianggap sebagai salah satu bentuk pendidikan "tradisional", eksistensi pesantren dalam era modern sekarang ini tetap memperlihatkan vitalitas dan menjadi tumpuan alternatif bagi berbagai pilihan pendidikan. Hal ini disebabkan oleh berbagai faktor, salah satu di antara unsur kredibilitas pesantren tidak terlepas dari adanya kyai/tuan guru dengan kharisma dan ketenaranya. Kedudukan kyai/tuan guru lebih dari sekedar guru, tempat bertanya berbagai masalah, meminta fatwa dan perlindungan pernikahan serta selamatan, melainkan ia muncul sebagai pemimpin informal.

Sejak dekade 1970-an perubahan cukup berarti dalam dunia pesantren sebagai suatu lembaga pendidikan. Sejak itu, sistem pendidikan sekolah (Madrasah) diintroduksi ke lingkungan pesantren, mulai dari tingkat Madrasah Ibtidaiyah, Tsanawiyah, Aliyah, sampai Perguruan Tinggi. Sebelumnya, ciri khas pesantren justru terletak pada metode proses belajar mengajar yang di Jawa disebut weton dan sorongan. Namun demikian hadirnya sistem sekolah (klasikal) tersebut bagi kebanyakan pesantren lebih menunjukkan sebuah fenomena additif daripada substitutif. Walaupun ada anggapan sistem gabungan tersebut mengakibatkan kecenderungan menurunnya kualitas output sistem pesantren, langkah tersebut dipandang cukup akomodatif.

Masuknya unsur-unsur baru ke dalam dunia pesantren seperti dikemukakan di atas mengharuskan pesantren melakukan upayaupaya kreatif untuk menemukan formatformat pengembangan yang bersifat adaptif terutama berkaitan dengan aspek pola pembinaan pesantren yang tentu saja sudah dapat diduga mengalami perubahan-perubahan dari tradisi pembinaan yang sebelumnya dilakukan oleh para pengelola. Hal itu terutama berkaitan dengan adanya perluasan cakupan manajemen pesantren dari yang terkait secara langsung dengan pemerintah, dalam hal ini Departemen Agama, yang dengan demikian tidak lagi menjadikan ulama sebagai pemegang otoritas tunggal dalam manajemen pesantren. Perubahan lain terjadi dalam hal pengembangan orientasi pesantren guna memenuhi keseragaman tujuan pendidikan agama Islam mulai dari tingkat Ibtidaiyah, Tsanawiyah, Aliyah atau bahkan memenuhi tujuan pendidikan umum bagi 
pesantren yang menyelenggarakan pendidikan umum, dari yang sebelumnya lebih ditekankan pada tujuan yang lebih praktis yaitu pehciptaan kader ularaa.

Selama itu, pola pembinaan ini penting ditelusuri mengingat adanya kecenderungan terjadinya ketegangan dalam pengelolaan pesantren akibat diintroduksinya sistem baru di satu pihak dan adanya tarik menarik antara sistem kharismatik tunggal kyai dengan sistem organisasi yang dibakukan.

Oleh karena itu penelitan ini ingin menjawab dua pertanyaan yaitu bagaimana corak kepesantrenan setelah terjadi perubahan sistem pendidikan pesantren, yang kedua, bagaimana perubahan itu berpengaruh terhadap sistem pengelolaan pesantren.

Namun dari penelitian ini ternyata kharisma kyai/tuan guru, tetap dapat dipertahankan. Walaupun sistem manajemen modern dan sistem klasikal telah diterapkan, bahkan hal tersebut telah banyak membantu aktifitas kyai/tuan guru sehingga figur ini tetap menjadi kunci penentu setiap kebijakan. Dengan demikian kharisma kyai/tuan guru semakin tinggi dan mantap apalagi dengan output pondok pesantrennya yang diakui berbobot oleh masyarakat dengan ciri khas yaitu tahfizul Quran.

Penelitian ini bertujuan untuk memperoleh pengetahuan berkenaan dengan corak penyelenggaraan pesantrenpascaterjadinya perubahan sistem pendidikan pesantren dengan diterapkannya sistem klasikal.

Penelitian ini juga bertujuan menelusuri akibat-akibat manajerial yang terjadi dalam pembinaan pesantren sebagai respon terhadap adanya perubahan sistem.

Kegunaan Penelitian ini bagi Departemen Agama sangat bermanfaat untuk menyusun kebijaksanaan dalam bidang pendidikan agama Islam, khususnya berkaitan dengan pengembangan pesantren sebagai suatu lembaga pendidikan dengan basis sosial yang kuat dan telah teruji sepanjang sejarah pendidikan Islam di Indonesia.
Adapun penelitian ini merupakan studi kasus di Pondok Pesantren Al Aziziyah Desa Gunungsari Kecamatan Gunungsari Kabupaten Lombok Barat.

Pengambilan data dilakukan dengan metode :

- Wawancara mendalam dengan kyai/tuan guru dan pengurus lembaga serta beberapa santri.

- Pengamatan terhadap kegiatan pesantren

- Studi dokumen-dokumen dan tulisan-tulisan yang berkaitan dengan pesantren.

Data yang telah dikumpul, dianalisis dengan menggunakan metode desktriptif interpretatif, yaitu metode yang lazim digunakan dalam penelitian kualitatif dengan melakukan penggambaran fenomena yang ada menurut apa adanya dan kemudian melakukan interpretasi sesuai dengan perspektif masyarakat.

\section{Temuan}

Pondok Pesantren Al Aziziyah menggunakan sistem klasikal sekaligus sistem halaqah dengan manajemen modern. Dengan sistem manajemen modern, maka tugas pengelolaan administrasi dan pelaksanaan kegiatan belajar mengajar sudah terbagi habis kepada wakil ketua - wakil ketua sesuai pembidangan masing-masing. Walaupun menggunakan kurikulum Departemen Agama, tetapi muatan lokal tetap dipertahankan dengan kekhususan tahfidzul Quran. Pondok pesantren ini menggunakan sistem klasikal dan halaqah dengan manajemen modern, namun dengan kepengurusan sistem keluarga, maka figur tuan guru tetap menjadi decition maker dalam setiap kebijakan pondok.

\section{GAMBARAN UMUM LOKASI}

Pondok Pesantren Al Aziziyah terletak di Desa Gunungsari Kabupaten Lombok 
Barat. Desa ini terdiri dari sebelas dusun, yaitu Dusun Gunungsari, Dusun Guntur Macan, Dasanbara, Rendang Bajur, Landang Bajur, Kapeg, Balai Kawu, Pakel, Medas Desa, Medas Barat Kokok dan Medas Badugul.

Batas wilayah Desa Gunungsari:

Sebelah Timur berbatas dengan Desa Tamansari

Sebelah Barat berbatas dengan Desa Sandaq

Sebelah Utara berbatas dengan Desa Kekait

Sebelah Selatan berbatas dengan Desa Midang.

Penduduk Desa Gunungsari ini terdiri dari penganut agama Islam 15.244 jiwa, Kristen Protestan 48 jiwa, Katholik 18 jiwa dan Hindu 342 jiwa. Adapun lapangan kerja mereka adalah pedagang, berkebun dan buruh tani.

Letak Pondok Pesantren Al Aziziyah ini di Dusun Kapeg tempat kelahiran Tuan Guru Haji Musthofa Umar Abdul Azis sebagai pendiri pondok pesantren ini. Dusun Kapeg terkenal sebagai daerah peternakan sapi, hanya pada umumnya masyarakat desa bukan sebagai pemiliknya tetapi sebagai buruh yang diupah. Di samping itu, di antara mereka ada yang bekerja sebagai makelar sapi. Oleh karena itu kehidupan masyarakat dusun Kapeg dapat dikatakan sangat sederhana. Kegiatan lain dari masyarakat dusun adalah bekerja sebagai pedagang kecil-kecil dan buruh kasar.

Gambaran di atas menunjukkan bahwa kondisi sosial ekonomi masyarakat bervariasi tetapi yang paling dominan adalah mereka yang hidup pas-pasan. Kondisi seperti ini mengakibatkan anak-anak mereka banyak yang tidak dapat mengenyam pendidikan lanjutan seperti SLTP dan SLTA. Mereka setelah tamat SD sudah dijadikan tenaga produksi keluarga dengan aktif menjadi buruh kebun, buruh peternakan sapi atau aktif berjualan membantu orangtuanya meningkatkan kesejahteraan keluarga. Di antara mereka sejak kecil sudah membantu keluarga dalam bidang industri rumah tangga berupa anyaman bambu untuk pembuatan dinding, meja, kursi dan lain-lain.

Keberadaan Pondok Pesantren Al Aziziyah dirasakan manfaatnya oleh masyarakat Dusun Kapeg dan Desa Gunungsari karena mereka punya peluang untuk meningkatkan wawasan keagamaan anak dan keluarga mereka dengan mengikuti pengajian rutin khusus untuk masyarakat umum yang diadakan setiap minggu dua kali dengan waktu yang terpisah antara kaum ibu dan kaum bapak. Bagi kaum bapak diadakan setiap Rabu pagi dan Jum'at pagi untuk kaum ibu diadakan setiap Senin dan Kamis jam 14.00 - Ashar. Pondok Pesantren ternyata membuka diri berintegrasi dengan masyarakat sebagai wujud pengabdiannya untuk masyarakat. Oleh karena itu keberadaan Pondok Pesantren dianggap sebagai milik masyarakat.

Masyarakat merasakan pondok pesantren sebagai benteng untuk menghadapi tantangan globalisasi saat ini dimana dengan perkembangan sarana komunikasi dan transportasi, turis asing dan domestik telah masuk desa dan dusun membawa kultur dan budayanya yang kadang-kadang bertentangan dengan adat dan agama. Hal ini dapat dimengerti karena jarak pondok pesantren dengan pantai Sengigi yang merupakan daerah rekreasi pantai yang menarik, hanya $\pm 4 \mathrm{~km}$. Oleh karena itu peranan pondok pesantren sangat diharapkan oleh umat maupun pemerintah daerah sebagai benteng bagi masyarakat dari pengaruh negatif akibat masuknya wisatawan asing dan domestik ke desa. 


\section{m. PROFIL PONDOK PESANTREN AL AZIZIYAH LOMBOK BARAT}

Latar Belakang Historis Pesantren

Tuan Guru Haji (TGH) Musthofa

Umar Abdul Azis merupakan pendiri Pondok

Pesantren Al Aziziyah (nama pesantren dinisbahkan dari nama kakeknya sebagai penyebar agama Islam). TGH Musthofa Umar lahir di Dusun Kapek Desa Gunungsari Kecamatan Gunungsari Kabupaten Lombok Barat (NTB) tepatnya pada tahun 1935. Beliau belajar agama di Ma'had Nahdatul Wathan Pancor dengan TGH Zainuddin yang terkenal pada tahun 1965 - 1977. Setelah kembali ke Dusun Kapek, beliau mendirikan Madrasah Nahdatul Muslimin Wal Muslimat. Madrasah ini beliau bina bersama-sama kakak kandungnya yang juga pernah belajar dari Mekah yaitu TGH Sakkaki Umar. Namun semangat untuk mendalami ilmu agama ke Mekah menggebu-gebu. Maka dengan keyakinan penuh pada tahun 1977 TGH Musthofa Umar berangkat bersama anak-anaknya yaitu Fauzul Banan, Fathul Azis, Fujiati, Fauzan Musthofa, Fawaz Musthofa dan Zakiah sebagai anak bungsu. Adapun anak yang tertua tetap di Mataram yaitu Drs. H. Munawir Mustofa dan $H$. Munawar, SH, keduanya belajar di Mataram dan tidak ikut orangtua ke Mekah.

Pada tahun 1985 TGH Musthofa Umar bersama-sama anak-anaknya kembali ke dusun Kapek Desa Gunungsari dan bertekad untuk mendirikan pesantren khusus Tahfidzul Quran. Hal ini dilatarbelakangi oleh tiga hal, yaitu ; (1) Merupakan tanggungjawab moral bagi beliau dan putra-putrinya yang baru menyelesaikan tugas belajar dan mengajar di Ma'had Al Haram Mekah guna mengamalkan ilmunya yang merupakan amanah dari Allah dan gurunya (2) Di Daerah Lombok khususnya dan NTB pada umumnya belum ada pesantren yang secara khusus mengelola Tahfidzul Quran dengan metode terapan seperti Darul Arqam Mekah (3) Kecamatan Gunungsari dengan pantai Senggigi merupakan pusat keramaian pariwisata di Nusa Tenggara Barat yang tentunya diperlukan filter yang kuat berupa iman serta ilmu agama bagi masyarakatnya.

Pada awalnya pondok pesantren mengadakan Ma'had Tahfidzul Quran dengan meminjam tempat di Mesjid Ussisa Al Attaqwa Dusun Kapek dengan santriwan dan santriwati sejumlah 150 orang. Pada tahun 1986 dimulai pembangunan pisik berupa mesjid dan asrama. Seiring dengan pembangunan pisik dan semakin banyaknya masyarakat yang ingin memondokkan anakanaknya, maka pada tahun 1986 didirikan Madrasaha Aliyah, Ma'had Diniyah (sekarang Madrasaha Quran Wal Hadist disingkat MQWH) tahun 1987, Madrasah Tsanawiyah dibuka tahun 1993, Taman Kanak-Kanak Alquran dibuka tahun 1993, dan Takhassus dibuka tahun 1995. Untuk mengembangkan dan meningkatkan kualitas pendidikan maka lembaga ini diperkuat dengan akta pendirian yayasan No. 46 tahun 1989 dengan struktur organisasi pondok pesantren yang akan dibahas secara khusus.

Sesuai dengan tujuan umum Pondok Pesantren Al Aziziyah yaitu ingin menanamkan dan meningkatkan ruhul Islam dalam prikehidupan beragama secara individu maupun bermasyarakat berdasarkan keikhlasan beribadah serta pengamalan syariat Islam secara murni dalam wadah Negara Kesatuan Republik Indonesia yang berdasarkan Pancasila dan UUD 1945 menuju ridha Allah swt, maka pesantren ini telah memprogramkan berbagai lembaga pendidikan formal dan informal dengan tiga pola pengembangan yaitu :

- Pola pembinaan hafalan Alquran dan Kutubul Mu 'tabarah (Kibat Kuning)

- Pola pembinaan pendidikan dengan kurikulum SKB 3 Menteri/Depag (khusus pendidikan formal).

- Pola pembinaan kemampuan berbahasa 
Arab dan Inggris serta pengembangan keterampilan seperti: pertukangan, jahit menjahit, peternakan, pertanian, komputer dan lain-lain.

\section{Potensi Fisik Pesantren}

\section{Fasilitas Ruang Belajar}

Pondok pesantren ini berdiri di atas tanah dengan luas areal mencapai 3,5 ha. Di atas tanah itu dibangun Mushalla dua buah masing-masing untuk putra dan putri. Asrama putri sebanyak 15 lokal, asrama putra 28 lokal, ruang belajar 28 lokal, kantor 5 lokal, ruang guru 1 lokal, Koperasi 2 lokal, ruang komputer 1 lokal, ruang keterampilan 1 lokal, perpustakaan 1 lokal, mesin air/PAM 3 buah dan listrik 8750 Volt.

Kampus Pondok Pesantren Al Aziziyah ini cukup megah dengan 3 gedung sekolah yang masing-masing berlantai empat satu buah dan dua gedung berlantai dua. Ruang belajar terdiri dari 28 lokal dengan kondisi permanen. Adapun ruang belajar terdiri dari kursi yang berbentuk kursi kuliah tanpa meja sehingga cukup praktis karena pada kursi sudah dilengkapi tempat mencatat pada tangan kursi sebelah kanan. Adapun bagi guru terdapat sebuah kursi dan white boar yang digunakan guru untuk menulis. Kapasitas tiap lokal +45 siswa.

Di tengah kampus ini terdapat sebuah aula yang cukup luas terdapat di lantai dua gedung asrama putra, dan gedung ini digunakan sebagai tempat kegiatan Muhadharah (latihan pidato) bagi santriwan dan santriwati. Tepat di tengahtengah kampus terdapat sebuah mesjid yang cukup megah dengan kapasitas 350 orang jamaah untuk ruang tengahnya. Pada saat ini luas bangunan seluruhnya mencapai $+8.500 \mathrm{~m}^{2}$.

Dengan demikian potensi pisik Pondok Pesantren Al Aziziyah dianggap cukup memadai dan sangat mendukung kegiatan belajar mengajar para santri. Sistem penerimaan siswa dibatasi sesuai kapasitas asrama yang tersedia. Sering ditemukan adanya orangtua yang datang dari jauh dan mendambakan kiranya anaknya dapat dididik di pondok ini namun harus kecewa dan bahkan merengek kepada TGH Musthofa. Tetapi setelah diberikan pengertian tentang kondisi tempat dan rasa tanggungjawab terhadap keamanan mereka, maka mereka harus terima dengan lega.

\section{Pemondofcan}

Semua santri yang mengikuti pendidikan di Pondok Pesantren Al Aziziyah tinggal di asrama yang telah disediakan. Ada pengecualian bagi santri yang tinggal bersama orangtua atau famili di sekitar pondokan yaitu di dusun Kapek. Namun mereka harus mengikuti kegiatan pondok secara penuh.

Para santri yang masuk harus memiliki pakaian seragam yang disediakan oleh koperasi pondok berupa :

- Madrasah Tsanawiyah, 3 stel pakaian :

- Pramuka

- Abu - Putih

- Putih - Batik

- Madrasah Aliyah, selain 3 stel pakaian seragama di atas, ditambah dengan :

- Baju batik santri lama (lengan panjang)

- Almari.

Adapun uang sekolah relatif rendah, untuk Madrasah Tsanawiyah Rp 7.000,/bulan, Madrasah Aliyah Rp 7.500,/bulan, MQWH Rp 6.500,-/bulan demikian juga dengan Takhassus, sedang TPA dan TKA hanya Rp 2.000,-/bulan. Adapun uang sumbangan : murid lama 25.000,- dan murid baru Rp 60.000,-

Mengenai makanan santri tergantung selera masing-masing dimana yang tertinggi \pm 35.000,-/bulan. Dalam arti bahwa di pondok tersedia kantin dengan menu sederhana dan harga yang relatif murah. 
Asrama putra 28 lokal dan asrama putri 15 lokal. Diperkirakan setiap lokal, berkapasitas 25 santri. Dengan demikian asrama putra dapat menampung \pm 1075 santri. Karena desakan orangtua santri, maka pengembangan pembangunan asrama santri telah menjadi prioritas utama. Hal ini dimaklumi karena minat masyarakat untuk memasukkan anaknya ke Pesantren Al Aziziyah cukup besar. Hal ini diakui oleh TGH Musthofa. Bahkan banyak dari wali murid merengek-rengek minta agar anaknya dapat diterima. Tetapi mereka kemudian sadar setelah dijelaskan oleh pendiri pesantren ini bahwa daya tampung asrama tidak cukup. "Santri adalah anak kami, dan amanah Allah kepada kami yang harus dijaga, dipelihara dan dididik dengan baik." kata Tuan Guru.

Dari apa yang diungkapkan di atas menunjukkan betapa besar tanggungjawab Tuan Guru terhadap para santri. Menurut Dhofier (1983 : 47) ada tiga alasan utama kenapa pesantren harus menyediakan asrama bagi para santri : (1) Kemasyhuran seorang kyai dan kedalaman pengetahuannya tentang Islam menarik santrisantri dari jauh untuk menggali ilmu dan menetap dekat Kyai. (2) Hampir semua pesantren berada di desa-desa yang tidak tersedia perumahan (akomodasi), maka untuk menampung santri perlu asrama, (3) Sikap timbal balik antara Kyai dan santri, dimana Kyai sebagai bapak dan santri sebagai anak titipan Tuhan yang senantiasa dilindungi.

Ketiga alasan ini pula bisa dijadikan titik tolak pemikiran sang Kyai sehingga prioritas utama yang akan dibangun adalah asrama. Sebab, walaupun di pesantren ini diadakan sistem klasikal seperti Madrasah, tetapi seluruh santri yang belajar di pondok ini diharuskan tinggal di asrama. Mmenurut Muslim Abdurrahman (1981 : 11), bahwa para santri dikelompokkan kepada dua kategori yaitu santri mukim dan santri kalong" (yang tidak tinggal asrama hanya datang sewaktu jam belajar, tetapi untuk Pesantren Al Aziziyah, yang diperkenankan seperti itu khusus bagi mereka yang memiliki rumah di sekitar pesantren).

Para santri memang dilatih sederhana. Mereka tidur dengan menggelar tikar di lantai tanpa kasur, sedang tas pakaian dan lemari pakaian mereka bersandar ke dinding. Umumnya pada hari Jum'at pagi mereka gunakan waktu untuk mencuci pakaian dan menyetrikanya nanti pada waktu sore hari. Pada waktu luang mereka dapat melakukan kegiatan yang bervariasi. Ada yang asyik bermain tenis meja, ada yang nonton TV dan ada yang duduk di serambi mesjid atau di teras asrama juga di bawah pohon dengan Quran kecil di tangan dan mulut kelihatan berkomat-komit menghafal Alquran. Kelihatannya mereka pandai menggunakan waktu sehigga tiada hari tanpa kegiatan. Bahkan dari dalam asrama terdengar suara santri menghafal Alquran dengan lagu yang nyaring. Hal ini memang pemandangan yang sangat menarik dalam kehidupan di lingkungan pondok.

Banyaknya orangtua yang ingin menyekolahkan anaknya di Pondok Pesantren Al Aziziyah dari tahun ke tahun semakin meningkat. Tapi karena keterbatasan pemondokan maka kompetisi dalam mengikuti seleksi semakin ketat. Animo masyarakat menyekolahkan anak di pesantren ini juga antara lain karena prestasi yang telah dimiliki oleh pesantren yang cukup menonjol di bidang tahfidzul Quran seperti hasil pada MTQ baik di tingkat lokal, nasional dan internasional sering mendapat juara. Bahkan pada tahun 1997 ini prestasi di bidang pengetahuan umum juga menonjol yang ditunjukkan dengan NEM tetinggi untuk tingkat SLTA di NTB, Madrasah Aliyah Al Aziziyah termasuk peringkat III. 
3. Sumber Pembiayaan dan Pengelolaan

Pondok Pesantren Al Aziziyah memiliki sifat pengabdian yang tinggi dari tokoh pendiri dan keluarganya. Dengan sedikit kekayaan yang dimiliki serta usaha yang selama ini dikembangkan di bidang perkebunan kelapa dan lain-lain. TGH Musthofa telah mampu membangun pondok yang sangat sederhana. Namun karena desakan dari para orangtua santri dan masyarakat maka secara perlahan tapi pasti pondok pesantren mengembangkan sistem pendidikan klassikal pada tahun 1986 yang dimulai dengan Madrasah Aliyah, Ma'had Diniyah (sekarang MQWH) tahun 1987, Madrasah Tsanawiyah dibuka tahun 1993, TK Alquran 1993 dan Takhasus tahun 1995.

Untuk mengembangkan dan meningkatkan kualitas pendidikan maka lembaga ini diperkuat dengan akte pendidirian Yayasan No. 46 tahun 1989 dengan struktur organisasi pondok pesantren. Semua ini demi untuk mengarahkan pondok pesantren lebih memberikan prospektif output pendidikan di masa datang. Dengan adanya lembaga Yayasan Al Aziziyah ini maka pembenahan sistem pendidikan pondok pesantren diharapkan berkembang terutama dari segi manajemen pengelolaan administrasi dan keuangan.

Khusus berkaitan dengan keuangan dan pengalokasian dana untuk penyelenggaraan pendidikan, semuanya dapat diketahui dari hasil wawancara dengan sekretaris Yaysan (Drs. H. Munawir Musthofa) padatanggal 15 Juli 1997, bahwa semua kegiatan yang berkaitan dengan pendanaan harus melalui usulan kegiatan dari masing-masing unit yang telah dibicarakan melalui rapat intern unit. Kemudian hasil usulan tadi disampaikan kepada yayasan, dan keputusan yayasan itu diambil lewat rapat pengurus inti yayasan.

Dari keterangan di atas menunjukkan bahwa pengeluaran dana kegiatan harus melalui perencanaan yang jelas lewat Daftar Usulan Kegiatan (DUK) masingmasing unit. Dengan demikian yayasan dapat mengamati dan mengontrol setiap pelaksanaan kegiatan secara cermat serta dapat mengevaluasi. Namun dana yang dikelola yayasan hanya berkaitan dengan dana yang didapat dari wali murid dan masyarakat setempat. Dana tersebut semata-mata digunakan untuk kegiatan penyelenggaraan pendidikan, kegiatan santri dan pemeliharaan gedung. Adapun . dana yang digunakan untuk pengembangan bangunan gedung pondok pesantren yang diperoleh dari Pembina Yayasan AL Aziziyah Pusat di Jakarta (H. Hidayat Achyar, SH) sebagai penyandang dana, secara langsung ditangani oleh ketua yayasan yaitu TGH Musthofa. Beliau yang merencanakan dan mengontrol pelaksanaan bangunan serta menentukan bentuk bangunan tersebut.

Dari apa yang dikemukakan di atas terlihat betapa dan bagaimana kedudukan dan peranan Tuan Guru Haji Musthofa sebagai Pimpinan Pondok Pesantren Al Aziziyah. Beliau tampil sebagai pelaku dan penentu dengan memiliki kharisma yang cukup tinggi, baik di kalangan intern pondok pesantren maupun masyarakat di sekitarnya. Hal ini didukung oleh keberhasilan dan spesifikasi Pondok Pesantren Al Aziziyah di bidang Tahfidzul Quran. Dengan demikian keharuman nama Pondok Al Aziziyah diikuti pula oleh keharuman nama pengasuhnya.

4. Fasilitas Penunjang

Beberapa fasilitas penunjang yang diandalkan adalah kepustakaan dan laboratorium komputer. Dengan adanya kepustakaan maka para santri dengan mudah dapat mendapatkan berbagai bukubuku dan kitab-kitab kuning yang tidak beredar di toko-toko buku. Di samping itu 
CORAK PESANTREN AL AZIZIYAH DESA GUNUNGSARI

KABUPATEN LOMBOK BARAT PROPINSINUSA TENGGARA BARAT

dengan kepustakaan yang terbuka, mereka dapat dengan tekun membaca dan mempelajari berbagai kitab yang ada sehingga wawasan pengetahuan agama mereka semakin luas.

Adapun laboratorium komputer dirasakan manfaatnya dalam rangka mendorong para santri untuk mengetahui dan menggunakan teknologi maju sehingga tidak ketinggalan dengan masyarakat perkotaan lainnya. Demikian pula bagi pihak yayasan dapat memanfaatkan tenaga-tenaga senior dari para santri untuk membantu penyelesaian administrasi kantor dengan melibatkan mereka dalam berbagai kegiatan seperti penerimaan siswa baru, penyelenggaraan kegiatan hari besar Islam seperti Maulid Nabi saw, dan kegiatan pondok lainnya.

Demikian pula adanya fasilitas olahraga seperti lapangan pondok dan meja pimpong. Lapangan pondok digunakan oleh para santri untuk berlatih olahraga silat Tapak Suci. Fasilitas meja pimpong juga dapat digunakan untuk meningkatkan kesegaran tubuh setelah belajar dengan bermain tenis meja. Tidak kurang pentingnya fasilitas aula yang digunakan untuk kegiatan muhadharah (latihan pidato) bagi para santriwan dan santriwati. Kegiatan muhadharah ini dilaksanakan pada Jum'at sore untuk santriwati dan setiap malam Jum'at untuk santriwan. Dengan demikian diharapkan setelah mereka terjun ke masyarakat mereka akan menjadi da'i yang handal, di samping sebagai hafidz dan hafidzah.

Fasilitas lain yang sangat mendukung adalah asrama santri yang telah tersedia bagi para santri yang datang dari luar kota. Mereka tidak terlalu repot mencari pemondokan yang memenuhi syarat kesehatan di luar pondok. Dan yang lebih penting keamanan mereka terjamin serta kesempatan mereka mengikuti semua kegiatan pondok tentu lebih besar. Hal ini sangat membantu dan membahagiakan santri dan para orangtuanya.

Potensi Sumber Daya Manusia

\section{Tenaga Edukasi}

Pondok Pesantren Al Al Aziziyah telah dapat menampilkan prestasinya di tengah masyarakat baik di bidang khusus Tahfidzul Quran yang telah banyak menghasilkan hafidz dan hafidzah juga dalam persaingan prestasi belajar antar sekolah ternama di Nusa Tenggara Barat. Madrasah Aliyah dan Madrasah Tsanawiyah dengan kurikulum Departemen Agama dan SKB 3 menteri, dari Pondok Pesantren Al Aziziyah telah menunjukkan prestasinya yang cukup menggembirakan, dengan merebut juara III dalam peroleh NEM tertinggi untuk tahun ajaran 1996/1997 baru-baru ini.

Semua itu tentu tidak terlepas dari metode pengajaran dan kualitas pendidikan. Dalam bidang pengajaran yang bersifat klassikal lebih ditekankan agar guru bidang studi yang ahli di bidangnya yang menjadi pengajar. Hal ini dapat kita lihat dari komposisi guru yang mengajar di Pesantren tersebut yaitu guru bidang studi Bahasa Arab misalnya H. Fujiati Musthofa, Abdul Hanan Lc dan M. Shidqi Abbas adalah keluaran Ma'had Al Haram Mekah, lembaga bahasa Arab Jakarta, dan Ma'had Nurul Hakim Kediri. Demikian pula yang mengajar nahu dan syaraf adalah H. Muchtar, dan M. Zaini yang mengajar seni membaca Alquran, keluaran Al Islahuddin Kediri.

Sedang yang mengajar.Tafsir dan Ushul Fiqhi adalah Fauzi Ashar dari Ma'had Al Haram Mekah. Fathul Azis Mustofa dari Ma'had Al Haram Mekah mengajar Quran dan Hadist serta Tah- 
fidzul Quran. Demikian pula dengan pengajar Fiqh'yaitu Mahsun Saleh dari Ma'had Al Haram Mekkah, juga H. Cholid Nawawi yang mengajar Quran dan Hadist. Sedang H. Ma'syura Saleh dari Ma'had Nahdatul Aulad mengajar Akhlak, sedang Muzakkar dari Takhassus Islahuddin Kediri mengajar Aqidah. Untuk materi pengajaran umum seperti Biologi, Matematika, Fisika, IPA, PPKN, Bahasa Indonesia dan Bahasa Inggeris diajarkan oleh guru bidang studi yang ahli di bidangnya dengan latar belakang sarjana pendidikan.

Dengan demikian maka kualitas yang diperlihatkan selama ini kepada masyarakat merupakan wujud dari terlaksananya sistem dan mutu pendidikan yang diterapkan oleh pondok pesantren.

2. Santri

Santri yang masuk belajar di pondok ini dari beragam latar belakang pendidikan baik dari pendidikan umum seperti SD, SLTP atau pendidikan agama seperti Madrasah Ibtidaiyah dan Tsanawiyah. Menurut informasi bahwa, untuk tingkat Tsanawiyah putra lebih dari separuh berasal dari latar belakang SD. Sedang untuk Aliyah lebih dominan berlatar belakang Madrasah Tsanawiyah. 
Adapun perkembangan kuantitas santri dapat dilihat tabel di bawah ini:

\begin{tabular}{|l|c|c|c|c|}
\hline \multirow{2}{*}{ Tingkat Pendidikan } & \multicolumn{4}{|c|}{ Keadaan Santri } \\
\cline { 2 - 5 } & Tahun & 1995 & \multicolumn{2}{c|}{ Tahun 1996} \\
\cline { 2 - 5 } & Orang & Kelas & Orang & Kelas \\
\hline Tahfidzul Quran & 150 & - & 800 & 4 \\
\hline TK Alquran & - & - & 178 & 8 \\
\hline Mad. Diniyah (MQWH) & - & - & 259 & 10 \\
\hline Mad. Tsanawiyah & - & - & 451 & 12 \\
\hline Madrasah Aliyah & - & - & 188 & 6 \\
\hline Takhassus & - & - & 20 & 1 \\
\hline Jumlah & 150 & - & 1896 & 40 \\
\hline
\end{tabular}

Sumber : Pesantren Al Aziziyah

Adapun pendidikan Madrasah Quran Wal Hadist (MQWH), dari wawancara dengan santriwan dan santriwati diperkirakan bahwa yang berlatar Madrasah Aliyah dari luar Al Aziziyah dan SD yang terbanyak. Adapun yang sarjana hanya satuorang. Yang ditekankan sebagai siswa MQWH adalah mampu berbahasa Arab.

Pendidikan Takassus berasal dari siswa Aliyah Al Aziziyah dan siswa MQWH. Mereka inilah yang diharapkan setelah mengikuti pendidikan tiga tahun akan menjadi Hafidz dan Hafidzah yang banyak mengetahui masalah agama. Jumlah santrinya 20 orang.

Corak Kepesantrenan

1. Status Halaqah dalam Sistem Pesantren

Halaqah adalah ciri utama pondok pesantren yang masih dipertahankan oleh pesantren ini. Pesantren Al Aziziyah ini ditekankan pada kemampuan menghafal Alquran. Di samping itu juga Halaqah diadakan untuk peningkatan kemampuan memahami agama dengan baik lewat Fiqh.

Fokus utama Halaqah adalah Tahfidzul Quran sehingga materi yang banyak ditampilkan adalah berkaitan dengan Tajwid dan seni membaca Alquran. Di samping itu materi tersebut juga diselingi dengan Fiqh, bahasa Arab dan bahasa Inggris. Selingan ini diatur menurut skedul jadwal yang telah ditetapkan.

Dengan demikian peran Halaqah sangat diharapkan untuk melahirkan output yang ahli di bidang Tahfidzul Quran. Hal ini menjadi kebanggaan santri dan masyarakat Nusa Tenggara Barat saat ini. Oleh karena itu banyak dari Pondok Pesantren yang ternama di Nusa Tenggara Barat mengirimkan kadernya untuk meningkatkan Tahfidzul Quran di Pondok Pesantren Al Aziziyah.

Bagi mereka yang telah menghafal Alquran 1 - 5 juz, mereka akan menghadap ustadz Fathul Azis, melaporkan siap untuk diuji. Setelah ditentukan waktunya, 
santri menghadap dan membaca juz yang dihafalnya. Ustadz Fathul Azil langsung menegur dan memperbaiki bacaannya kalau salah, dan setelah selesai membaca maka Ustadaz Fathul Azis Musthofa memberikan penilaian untuk melanjutkan juz berikut atau menghafal ulang lagi dengan bacaan yang tepat. Bila sudah lolos ke juz berikut Ustadz Azis mencatat nama dan dari Madrasah kelas berapa dan hafalan sampai juz berapa. Bila sudah tamat 30 juz, Ustadz Fathul Azis melapor kepada TGH Musthofa dan dikukuhkan telah menjadi hafidz.

Dari data di atas ternyata jumlah Tahfidzul Quran dari 150 orang pada tahun 1985 sekarang sudah mencapai 800 orang pada tahun 1996. Adapun santri yang sudah menghafal 30 juz ada 65 orang dimana 17 diantaranya adalah santriwati.

\section{Sistem Pelaksanaan}

Sebagaimana telah dikemukakan sebelum ini bahwa Pesantren Al Aziziyah lebih memfokuskan outputnya pada bidang Tahfidzul Quran. Untuk itu Halaqah yang ditampilkan materinya adalah berkaitan dengan Tajwid dan seni membaca Alquran.

Sistem Halaqah ini diberikan oleh beberapa kader yang sudah mampu menghafal 30 juz Alquran dengan baik. Halaqah ini dilaksanakan secara berkelompok antara 20-30 orang dengan pimpinan seorang guru. Halaqah dilaksanakan pada ruangan kelas masing-masing. Waktu melaksanakannya adalah sore hari sesudah shalat Ashar dan pada malam hari sesudah shalat Isya. Setelah selesai Halaqah dilanjutkan dengan materi pelajaran tambahan sesuai jadwal yaitu bahasa Inggris, bahasa Arab dan Fiqih. Ketiga materi inilah yang diperdalam para santri untuk masing-masing kelas. Sedang pada hari libur dan waktu-waktu senggang mereka sibuk menghafal Alquran.

Walaupun yang ditekankan harus menghafal 30 juz hanya santri MQWH setiap semester harus hafal 5 juz, namun bagi santri Madrasah Tsanawiyah dan Aliyah juga gigih menghafal Alquran.
Dapat dikatakan bahwa tiada hari tanpa menghafal Alquran. Mereka dari Madrasah Tsanawiyah dan Aliyah hanya dihimbau agar cukup mengahafal 2 juz setiap semester. Namun banyak di antara mereka yang melampaui target tersebut. Suasana kompetitif yang positif dalam menghafal Alquran merupakan fenomena yang cukup menarik dari pondok pesantren ini. Mereka umumnya bertekad untuk tidak gagal setelah tamat dari Pesantren Al Aziziyah minimal dapat menghafal 10 - 20 juz. Inilah beberapa kesimpulan dari wawancara dengan beberapa siswa Tsanawiyah.

Dari wawancara dengan pengurus mengatakan bahwa kesungguhan para santri untuk mencapai tingkat kemampuan hafal Alquran yang memadai cukup besar. Tingkat Tsanawiyah ternyata untuk kelas III dari putra 3 orang dan putri 1 orang telah mampu menghafal 30 juz Alquran, sedang yang lainnya telah menghafal antara 6 - 10 juz.

Dari Madrasah Aliyah ternyata sejak kelas I tidak ada yang tidak dapat menghafal Alquran minimal 1-5 juz. Semua ini menggambarkan bahwa pesantren dengan ciri khusus Tahfidzul Quran, masih tetap eksis.

\section{Kurikulum}

Dalam membicarakan kurikulum, maka akan dibicarakan kurikulum yang berkaitan dengan sistem belajar klasikal sesuai dengan perkembangan tingkat pendidikan yang ada di pondok pesantren ini.

Madrasah Tsanawiyah dan Madrasah Aliyah

Kurikulum yang digunakan adalah kurikulum SKB 3 Menteri/Departemen Agama. Di samping itu diadakan kurikulum terpadu, seperti : Madrasah Tsanawiyah. 
CORAK PESANTREN AL AZIZIYAH DESA GUNUNGSARI

KABUPATEN LOMBOK BARAT PROPINSINUSA TENGGARA BARAT

KURIKULUM MADRASAH TSANAWIYAH AL AZIZIYAH

\begin{tabular}{|c|c|c|c|c|c|c|c|c|}
\hline \multirow{2}{*}{ M 0 \& 1 r } & \multicolumn{4}{|c|}{ Kurikulum Depag } & \multicolumn{4}{|c|}{ Kurikulum Terpadu } \\
\hline & $\mathbf{I}$ & I I & I I I & Total & $\mathbf{I}$ & I I & I I I & Total \\
\hline $\begin{array}{l}\text { 1.Pendidikan Agama } \\
\text { a.Quran \& Hadist } \\
\text { b.Aqidah Akhlak } \\
\text { c.Fiqh } \\
\text { d.SKI } \\
\text { e.Bhs. Arab } \\
\text { 2.PPKN } \\
\text { 3.Bhs. Indonesia } \\
\text { 4.Matematika } \\
\text { 5.IPA Biologi } \\
\text { Fisika } \\
\text { 6. IPS } \\
\text { 7.Ket.Tangan \& Ke- } \\
\text { senian } \\
\text { 8.Penjas \& Kes. } \\
\text { 9.Bhs. Inggris } \\
\text { lO.Muatan Lokal } \\
\text { - Tahfidzul Quran }\end{array}$ & $\begin{array}{l}1 \\
2 \\
2 \\
1 \\
3 \\
\\
2 \\
6 \\
6 \\
3 \\
3 \\
6 \\
2 \\
\\
2 \\
4 \\
2\end{array}$ & $\begin{array}{r}1 \\
\mathbf{2} \\
\mathbf{2} \\
\mathbf{1} \\
\mathbf{3} \\
\mathbf{2} \\
\mathbf{6} \\
\mathbf{6} \\
\mathbf{3} \\
\mathbf{3} \\
\mathbf{6} \\
\mathbf{2}\end{array}$ & $\begin{array}{l}2 \\
6 \\
6 \\
3 \\
3 \\
6 \\
2\end{array}$ & $\begin{array}{r}3 \\
6 \\
6 \\
3 \\
9 \\
\\
6 \\
18 \\
18 \\
9 \\
9 \\
18 \\
6 \\
6 \\
12 \\
6\end{array}$ & $\begin{array}{l}2 \\
2 \\
4 \\
2 \\
4 \\
\\
2 \\
6 \\
6 \\
3 \\
3 \\
6 \\
2 \\
\\
2 \\
x \\
x\end{array}$ & $\begin{array}{l}2 \\
6 \\
6 \\
3 \\
3 \\
6 \\
2\end{array}$ & $\begin{array}{l}2 \\
2 \\
4 \\
2 \\
4 \\
2 \\
6 \\
6 \\
3 \\
3 \\
3 \\
6 \\
2 \\
\\
2 \\
x \\
x\end{array}$ & $\begin{array}{r}6 \\
6 \\
12 \\
4 \\
12 \\
12 \\
18 \\
18 \\
9 \\
9 \\
18 \\
6 \\
6 \\
\times \text { ( s ore } \\
\times \text { ( s ore }\end{array}$ \\
\hline Jumlah & 45 & 45 & 45 & 135 & 48 & 48 & 48 & 144 \\
\hline
\end{tabular}

Sumber : Pesantren Al Aziziyah

Dengan demikian, maka kurikulum

KelasI

terpadu telah membawa nilai tambah kepada santri yang belajar di Tsanawiyah khusus di bidang pengetahuan agama dan bahasa Arab serta bahasa Inggris dan Tahfidzul Quran. Di samping itu metode Halaqah untuk materi Tajwid dan seni baca Alquran serta Fiqh merupakan muatan yang sangat bermanfaat bagi mereka.

Adapun kurikulum Aliyah sesuai SKB 3 Menteri ditambah kurikulum terpadu dimana khusus pendidikan agama diberikan tambahan jam pelajaran seperti di atas.

Madrasah Quran Wal Hadist (MQWH)

Adapun MQWH mempunyai kurikulum lokal dengan tingkat penjenjangan sampai kelas VI.

- Mufhalaah

- Imla/Khod

- Mahfudhah (Kata Mutiara)

- Aqidah

- Terjemahan Alquran

- Bahasa Arab

- Akhlaqul Banat (sampai kelas III)

- Tajwidul Quran (sampai kelas III)

Kelas II : Sama dengan di atas (kelas I) hanya ditambah :

- Hadist Arbain

- Bahasa Inggris

- Nahu

Kelas III : Sama dengan kelas II hanya ditambah :

- Nahu dan Syaraf

Kelas IV :

- Ushul Fiqh

- Buluqul Maram 
- Tafsir

- Hadist Riadshalihin

- Faraid

- Bahasa Inggris

- Bahasa Arab

Kelas V dan Kelas Vi sama dengan Kelas IV hanya kitab yang digunakan lebih tinggi dari kelas di bawahnya.

Bagi santri MQWH diwajibkan tamat menyelesaikan hafalan Alquran 30 juz.

Takhassus

Materinya sama dengan MQWH yang di kelas IV, V, VI kitab-kitabnya yang berbeda.

Kitab-kitab yang dipakai antara lain : Tafsir : Tafsir Jalalain, Saffatul Tawasir

Hadist : Riaduskshallihin, Buluqul Muram, Hadist Arbain

Fiqh : Fathul Qarib

Ushul : Mabadi'ul Awwaliyah,

Fiqh Qatrum Nada'

Aqidah : Sabilun Najab

Al Ushul

Tarich : Shiratul Syaidil Mursalin

Akhlak: Akhlaqul Lilbanin

"Al Burhan"

Bahasa: An Nasyi'in

Arab

Faraid : Mazmu'ul Ar Rawiah

Nahu : Mutammimah

Para santri selain mengikuti sistem klasikal dengan kurikulum terpadu maka semuanya harus mengikuti Halaqah berkaitan dengan Tahfldzul Quran. Dan bagi santri Takhassus belum selesai menghafal Alquran 30 juz agar segera menghafalkan Alquran dalam tingkat pertama ini.

Aspek Pembinaan Pesantren

1. Struktur Organisasi

Adapun struktur organisasi Pondok Pesantren Al Aziziyah adalah sebagai berikut :

- Pembina/ : H.Hidaya Achyar,SH (Jakarta)

Ketua Umum

\author{
- Ketua/ : TGH Musthofa Umar Abd.Azis \\ Mudir \\ - Bidang : H.Djamaluddin Oemar (Jakarta) \\ Pemb. \\ - Sekretaris : Drs.H.Munawir Musthofa \\ Umum \\ - Wk.Ketua : Akmaluddin \\ Bid.Pend. \& \\ Pengajaran \\ - Wk.Ketua : H.Fathul Azis Musthofa \\ Bid. Pengasuh \\ Santri \\ - Wk.Ketua : Yoyo Wardoyo, S.Pd \\ , Bid.
}

Dari struktur organisasi di atas dapat dilihat bahwa Pembina/Ketua Umum H.Hidayat Achyar, SH berkedudukan di Jakarta, karena beliau seorang pengusaha. H. Hidayat selama ini telah memberikan bantuan dana yang cukup besar sehigga pengembangan dan pembangunan gedung Pondok Pesantren Al Aziziyah semakin megah. Dengan demikian sebagai penghargaan H. Hidayat didudukkan sebagai Pembina/Ketua Umum. Adapun TGH Musthofa selaku Ketua/Mudir merupakan pelaksana utama dan pendiri Pondok Pesantren Al Aziziyah.

Adapun tugas Ketua Umum/Mudir adalah :

I. Bertanggungjawab ke dalam/keluar atas segala program di pondok pensantren.

2. Mengkoordinasikan setiap kegiatan pembina pusat seperti merencanakan dan melaksanakan pengembangan pondok baik dalam arti pisik maupun non fisik. Di samping itu merumuskan dan menetapkan kebijakan-kebijakan pondok pesantren ke arah kemajuan dan peningkatan kualitas santri. Juga memberikan penghargaan dan kesejahteraan guru-guru/ustaz sesuai dengan kondisi dan kemampuan pondok. Hal yang lebih penting adalah mengadakan hubungan kerja/koordinasi dengan pihak pemerintah, masyarakat dan swasta 


\section{CORAK PESANTREN AL AZIZIYAH DESA GUNUNGSARI KABUPATEN LOMBOK BARAT PROPINSI NUSA TENGGARA BARAT}

sepanjang sifatnya positif dan tidak merugikan pondok.

3. Melakukan pembinaan dan memberikan petunjuk-petunjuk dalam pelaksanaan program-program pondok pesantren kepada masing-masing lembaga.

4. Membina hubungan yang harmonis dengan wali murid dan masyarakat melalui pengajian umum dan kunjungankunjungan/undangan.

5. Mobilisasi dana-dana pembangunan dengan bidang pembangunan, bidang dana untuk pembangunan fisik.

Dari gambaran tugas TGH Musthofa di atas tergambar betapa besar wewenang dan tanggungjawab yang diemban oleh Ketua/Mudir. Dengan demikian semua kebijakan dalam bidang kualitas pendidikan dan pengajaran, bidang pengasuh santri, bidang kegiatan santri dan bidang dana/pembangunan berada di tangan TGH Musthofa Umar.

Di samping itu yang perlu digaris bawahi bahwa jabatan sekretaris umum adalah anak kandung tuan guru, demikian juga Wakil Ketua Bidang Pengasuh Santri. Sedang Wakil Ketua Bidang Pendidikan Pengajaran adalah besan dimana anak laki-laki Tuan Guru kawin dengan anak gadis dari Akmaluddin. Dengan demikian dominan pengurus lembaga adalah Keluarga Tuan Guru Haji Musthofa.

\section{Mekanisme Pengatnbilan Keputusan}

Dalam menentukan suatu kebijaksanaan baru maka setiap bidang mengadakan rapat intern bidang tersebut. Sebagai contoh untuk bidang Pendidikan dan Pengajaran misalnya terdiri dari beberapa sub bagian yaitu Perpustakaan, TK/TPA, Madrasah Tsanawiyah, Madrasah Aliyah, MQWH, Takhassus, Tahfidz, Bahasa dan Komputer. Masing-masing sub bagian itu dipimpin oleh seorang kepala. Mereka mengadakan pertemuan membicarakan secara bersama-sama tentang kebijakan berkaitan dengan peningkatan kualitas pendidikan dan program kerja yang mendukung hasil pertemuan tersebut untuk disampaikan kepada TGH Musthofa sebagai Ketua/Mudir. Setelah dipelajari, beliau memanggil pengurus inti yaitu Sekretaris Yayasan, dan ketiga Wakil Ketua. Setelah mendengar maksud dan latar program tersebut dari Wakil Ketua Bidang Pendidikan dan Pengajaran dan tanggapan dari anggota, maka Ketua mengambil keputusan.

Di samping itu, dalam mengambil keputusan untuk suatu program, maka bidang tersebut langsung mengundang Ketua untuk hadir mendengar masukan dari para sub bagian. Setelah mendengar semua saran, ketua menganjurkan supaya dibuatkan program kerja tertulis dan secara prinsip beliau telah setujui.

Dari apa yang dikemukakan di atas menggambarkan bahwa sistem musyawarah telah berjalan dengan baik, mekanisme kerja juga sudah jelas dengan tugas masing-masing dan tanggung jawabnya. Semua usulan dana untuk satu kegiatan misalnya harus didahului dengan mengajukan proposal kegiatan. Dengan melalui beberapa pertimbangan yang rasional, kemudian ketua mengabulkan secara utuh atau ada pengurangan di sana-sini sesuai dengan kondisi keuangan pondok.

Hal yang cukup menarik adalah tentang dana pembangunan pisik yang datangnya dari Pembina/Ketua Umum dari Jakarta sepenuhnya berada dalam wewenang Mudir. Beliau yang menangani langsung pembangunan pisik dan penggunaan dana, dimana secara langsung dipertanggungjawabkan kepada Ketua Umum di Jakarta. Adapun dana dari santri, orangtua santri dan masyarakat, hanya itulah yang dikelola oleh yayasan melalui mekanisme kerja yang telah dikemukakan di atas. Dana ini pula yang digunakan selain 


\section{CORAK PESANTREN AL AZIZIYAH DESA GUNUNGSARI KABUPATEN LOMBOK BARAT PROPINSINUSA TENGGARA BARAT}

untuk kegiatan pendidikan dan pengajaran, juga untuk kegiatan pondok pesantren dan pemeliharaan gedung.

Pembagian Tugas

Sebagaimana dikemukakan di atas bahwa lembaga Pondok Pesantren Al Aziziyah telah tersusun dalam bentuk susunan pengurus lengkap di bawah ini:

(1) Pembina/Ketua Umum

(2) Ketua/Mudir

(3) Bidang Pembangunan

(4) Sekretaris Umum

(5) Wakil Ketua Bidang Pendidikan dan Pengajaran

(6) Wakil Ketua Bidang Pengasuh Santri

(7) Wakil Ketua Bidang Kegiatan Santri

Sekretaris dibantu oleh Tata Usaha,

Keuangan, Bendahara, Perlengkapan,

Koperasi dan Humas. Adapun masingmasing wakil ketua dibantu oleh bagian seperti Wakil Ketua, Bidang Pendidikan dan Pengajaran terdiri dari Kepustakaan, TK/TPA, Madrasah Tsanawiyah, Madrasah Aliyah, Bahasa dan Komputer, Wakil Ketua Bidang Pengasuh Santri, terdiri dari bagian Organisasi Pelajar, Asrama, Logistik dan Poskestren. Wakil Ketua Bidang Kegiatan Santri terdiri dari bagian Orkes, Bagian Dakwah, Bagian Keterampilan dan Panti Asuhan.

Adapun tugas masing-masing bidang sudah terbagi habis dilaksanakan oleh bagian-bagian dengan personil yang ada. Tugas Ketua/Mudir sudah dijelaskan di atas dengan tugas, wewenang dan tanggungjawab yang cukup besar.

- Sekretaris Umum mempunyai tugas :

(1) Melaksanakan dan mengkoordinasikan tugas-tugas kesekretariatan, bidang tata usaha, bendahara, perlengkapan, sesuai dengan kegunaan.

(2) Melaksanakan tugas-tugas pendelegasian yang diberikan oleh pembina pusat dan Mudir dalam melaksanakan tugas Ketua/Mudir (Bidang Pendidikan dan
Pengajaran, Bidang Pengasuh santri dan kegiatan santri).

- Bidang Pembangunan dan Dana mempunyai tugas (bersama Mudir) ikut memikirkan penggalian sumber-sumber dana yang sah untuk pengembangan pondok pesantren.

- Wakil Ketua Bidang Pendidikan dan Pengajaran :

(1) Merencanakan dan melaksanakan dengan KIS kegiatan KBM masingmasing lembaga (TK/TPA, MTs, MA, MQWH, Tahfidz, Takhassus, Komputer dan Perpustakaan).

(2) Mengkoordinasikan tugas guru/ustadz dan kegiatan ekstra

(3) Melaksanakan kurikulum Depag dan MQWH

(4) Melaksanakan pendelegasian tugas khusus dari Mudir.

(5) Melaksanakan tugas-tugas dan tanggungjawab secara rinci dengan lembaga-lembaga yang ada.

- Wakil Ketua Bidang Pengasuh Santri, mempunyai tugas :

(1) Menjabarkan dengan koordinasi tugastugas bidang OSIS, asrama, logistik dan Poskestren.

(2) Melaksanakan sebagian tugas-tugas pendelegasian khusus dari Mudir.

- Wakil Ketua Bidang Kegiatan Santri, mempunyai tugas :

(1) Melaksanakan sebagian tugas-tugas pendelegasian khusus dari Mudir.

(2) Merencanakan dan melaksanakan tugas kegiatan santri bidang olahraga, dakwah dan BLP secara Koordinatif.

Dari tugas-tugas yang ditampilkan di atas ternyata masing-masing bidang kerja telah membagi habis tugas kepada masingmasing kepala bagian. Dan secara manajerial mekanisme kerja telah berjalan dengan baik.

Suatu hal yang menarik, dimana personil yang duduk pada posisi sentral adalah keluarga Tuan Guru sehingga 
sangat memperkuat posisi TGH Musthofa Umar sebagai pendiri pondok pesantren. Dari personil yang ada ternyata yang menduduki posisi sentral dari lembaga tersebut seperti Sekretaris Umum adalah anak kandung dari TGH Musthofa Umar, Wakil Ketua Bidang Pengasuh Santri adalah juga anak kandung TGH Musthofa Umar dan Wakil Ketua Bidang Pendidikan dan Penjaragan adalah besan TGH Musthofa. Kondisi ini menunjukkan bahwa sistem kepemimpinan yang ada merupakan sistem keluarga, sehingga diharapkan lembaga ini akan berjalan dengan langgeng dan estafet kepemimpinan masa depan akan berjalan dengan aman tanpa gejolak.

\section{Hubungan dengan Pihak Luar (Pemerin- tah, Swasta)}

Berbicara tentang hubungan Pondok Pesantren Al Aziziyah dengan pemerintah ternyata cukup baik. Hal ini dapat dilihat ketika penulis berada di rumah TGH Musthofa Umar dan sedang berbincangbincang di ruang tamu beliau, tiba-tiba terdengar suara salam dari luar. TGH Musthofa setelah menjawab salam tersebut, sambil mempersilahkan Pak Camat Gunungsari masuk, TGH Musthofa menyampaikan kepada Pak Camat bahwa sekarang saya mau ke Jakarta, bagaimana Pak Camat, apa ada perlu, Pak Camat menjawab bahwa saya ingin bicara empat mata, dan TGH. Musthofa mengajak keluar di teras dan hanya ?+ 10 menit mereka berbincang-bincang Pak Camat pamitpulang.

Menurut TGH. Musthofa bahwa hubungan dengan pemerintah cukup baik, karena dalam setiap Musabaqah, Pondok Pesantren Al Aziziyah sangat diandalkan oleh pemerintah daerah mulai dari tingkat kecamatan, kabupaten dan propinsi untuk membawa nama daerah. Namun, pemerintah daerah belum sempat memberikan bantuan bagi pengembangan dan pembangunan pondok pesantren.

Selain dari pemerintah daerah, hubungan dengan instansi terkait seperti
Departemen Agama di tingkat Kantor Wilayah dan Kabupaten cukup baik. Mereka itu membina dan memberikan arahan berkaitan dengan pengembangan pondok pesantren ini. Kerjasama dengan instansi Departemen Agama cukup baik dan bantuan moril dan materil seperti buku-buku agama selalu ada untuk pondok ini.

Kerjasama dengan perusahaan swasta cukup baik yaitu berkaitan dengan pengadaan buku-buku tulis untuk koperasi. Kerjasama dengan industri rumah tangga di desa ini cukup baik, seperti pembuatan kursi, meja dari bambu yang ditampung oleh koperasi pondok dan mendropnya kepada pertokoan yang ada di Mataram.

4. Unsur-Unsur Integrasi dan Konflik

Unsur-unsur integrasi dapat dilihat dalam setiap kegiatan yang diadakan oleh pondok pesantren. Kegiatan tersebut seperti peringatan Maulid Nabi saw, yang diikuti oleh masyarakat dan pemerintah daerah seperti camat dan bupati serta dari unsur Departemen Agama.

Selanjutnya berkaitan dengan masyarakat umum, integrasi terjadi melalui kegiatan pengajian bagi masyarakat. Pengajian khusus untuk kaum bapak diadakan setiap :

Rabu : jam $0800-09.00$

Jum'at : Jam 08.00-09.00

Sore : Jam 16.00 - 16.30

Khusus untuk kaum ibu :

Senin : Jam 14.00 - Ashar

Kamis : Jam 14.00 - Ashar

Pengajian umum untuk wali murid diadakan awal bulan pada:

Hari Sabtu jam 13.00 - Ashar.

Dari kegiatan di atas menunjukkan bahwa pondok pesantren ini membuka diri untuk berintegrasi dengan masyarakat. Hal ini telah mendekatkan pesantren dengan masyarakatnya dan akibat selanjutnya bahwa keberadaan pesantren sebagai milik masyarakat sangat diharapkan manfaatnya. 


\section{CORAK PESANTREN AL AZIZIYAH DESA GUNUNGSARI KABUPATEN LOMBOK BARAT PROPINSI NUSA TENGGARA BARAT}

\begin{abstract}
Adapun unsur konflik tidak terlalu nampak karena mekanisme kerja lembaga telah berjalan dengan ba.ik, dan dapat dikontrol kestabilannya dengan adanya dominan keluarga dalam struktur lembaga. Sedikit ada letupan dan telah dapat diantisipasi adalah adanya pendidikan yang bersifat klasikal yang didirikan bersama oleh TGH. Musthofa Umar dan TGH. Sakkali Umar yaitu Madrasah Nahdatul Muslim dan Muslimat, tapi dikembangkan menjadi Yayasan Addinul Qayyim oleh TGH. Sakkali setelah TGH. Musthofa Umar ke Mekah.

Pada awal 1985 sekembali dari Mekah TGH. Musthofa dan anak-anaknya mendirikan Pondok Pesantren Al Aziziyah dengan ciri khas Takfidzul Quran. Pada tahun 1986, ternyata banyak peminat dan para masyarakat mendesak untuk dikembangkan dengan sistem klassikal, maka didirikanlah Madrasah Aliyah dan Tsanawiyah. Pada saat itu ternyata TGH. Sakkali mempertanyakan hal itu, mengapa diadakan klassikal padahal di Yayasan Addinul Qayyim sudah ada. Namun dijawab oleh TGH. Musthofa bahwa ciri khasnya Al Aziziyah adalah Tahfidzul Quran. Tetapi selanjutnya masing-masing tokoh perguruan itu mampu mengendalikan diri sehingga konflik tidak muncul ke permukaan. Dari kenyataan di lapangan ternyata sampai saat ini kedua lembaga masing-masing berjalan dengan baik tanpa masalah.
\end{abstract}

\section{PENUTUP}

Kesimpulan

Dari hasil penelitian di atas dapat disimpulkan bahwa :

1. Pondok Pesantren Al Aziziyah merupakan pondok pesantren modern yang menggunakan sistem klassikal dan manajemen modern. Namun metode Halaqah masih tetap dipertahankan, sebagai salah satu ciri dari pondok pesantren di samping Kyai/Tuan Guru, Mesjid dan Kitab Kuning.

2. Satu hal yang cukup menarik dari pondok pesantren ini adalah ciri khasnya yang tidak ditemukan pada pondok pesantren yang lain di Nusa Tenggara Barat yaitu Tahfidzul Quran, dimana para lulusan pesantren tersebut mempunyai kelebihan dalam menghafal Alquran dengan tajwid dan lagu yang baik.

3. Walaupun sistem klassikal dan manajemen modern yang diterapkan di pesantren namun sistem Halaqah tetap dipertahankan. Ternyata figur Tuan Guru tetap menjadi orang yang disegani dan mempunyai kharisma yang tinggi baik keluar dan di lingkungan pondok pesantren. Dalam menentukan kebijakan tetap berada di tangan Tuan Guru.

4. Sifat keterbukaan Tuan Guru terhadap masyarakat terlihat jelas dengan adanya kegiatan pengajian khusus untuk kaum ibu dan kaum bapak dua kali dalam seminggu. Di samping itu juga diadakan pengajian khusus bagi orangtua santri setiap Sabtu siang jam 13.00 pada awal bulan. Hal ini jelas dalam rangka mengadakan integrasi dengan masyarakat sehingga pondok pesantren menjadi milik masyarakat.

5. Kekhususan pondok pesantren ini dibidang Tahfidzul Quran telah membawa perhatian khusus masyarakat umum dan Pemerintah Tingkat Propinsi Nusa Tenggara Barat. Bahkan banyak pondok pesantren ternama di Nusa Tenggara Barat mengirimkan kader dari pondoknya untuk mendalami Tahfidzul Quran di Pondok Pesantren Al Aziziyah.

6. Pengurus lembaga ini didominasi oleh • keluarga sehingga kharisma Tuan Guru serta mekanisme kerja di dalamnya mudah dapat dikontrol. Akibatnya lembaga ini tetap eksis dan tidak mudah digoyang. Estafet kepemimpinan pondok pesantren di masa datang telah terbina dengan baik tanpa masalah di kemudian hari.

- Saran-saran

1. Lembaga Pondok Pesantren Al Aziziyah diharapkan untuk meningkatkan jenjang pendidikannya setingkat Sekolah Tinggi 


\section{CORAK PESANTREN AL AZIZIYAH DESA GUNUNGSARI KABUPATEN LOMBOK BARAT PROPINSI NUSA TENGGARA BARAT}

\begin{abstract}
Agama Islam dikonversikan dengan kurikulum Departemen Agama sehingga ijazahnya diakui. Hal ini untuk membantu para santri dapat berkiprah dalam lembaga formal pemerintah atau lembaga non formal swasta dalam pengembangan dakwah Islamiyah.

2. Pengembangan kampus merupakan hal yang cukup mendesak. Oleh karena itu bantuan pemerintah daerah sangat diharapkan karena selama ini MTQ untuk Tingkat Nasional dan Internasional ternyata utusan dari pondok ini telah membawa harum nama bangsa dan daerah Nusa Tenggara Barat.
\end{abstract}

\section{KEPUSTAKAAN}

Abhar, TG. H. Mustiadi, Kegiatan Pondok Pesantren Darul Falah, Pagutan, Mataram, 1997.

Abdullah, Taufik, Agama dan Perubahan Sosial, Rajawali, Jakarta, 1993.

Dhofir, Zamachsyani, Tradisi Pesantren, LP3ES, Jakarta, 1982.

Muhdar, KH. Ahmad, Fungsi Pesantren dari

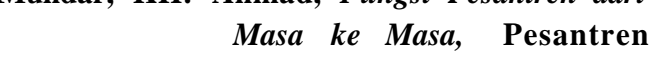

\author{
Luhur Malang, 1975. \\ Raharjo, Dawan, Pesantren dan Pem-
bangunan, LP3ES, Jakarta.
Raharjo, Dawan, Pesantren dan Pem-
bangunan, LP3ES, Jakarta. 1974.

Saifuddin, Ahmad Fedyani, Konflik dan Integrasi, CV, Rajawali, Jakarta, 1986.

Yusuf, Slamet Effendy, dkk. Dinamika Kaum Santri, CV. Rajawali, Jakarta, 1983.

Zainun, Muh., Kitab Istiqatsah At Thariqatul Mu 'tabarah Alqadririyah Wan Naqsyabandiyah, Ponpes Darul Falah Pagutan - Mataram, 1993. 